\title{
A Modified Method for the Synthesis of Tetradentate Ligand Involving Peptide Bond
}

\author{
Pulimamidi Rabindra Reddy*, Ravula Chandrashekar, Hussain Shaik, \\ Battu Satyanarayana \\ Department of Chemistry, Osmania University, Hyderabad, India \\ Email: *profprreddy@gmail.com
}

Received 10 April 2014; revised 15 May 2014; accepted 22 May 2014

Copyright (C) 2014 by authors and Scientific Research Publishing Inc. This work is licensed under the Creative Commons Attribution International License (CC BY). http://creativecommons.org/licenses/by/4.0/

\section{Abstract}

In view of the importance of picolinic acid $(\mathrm{Pa})$ in preventing cell growth and arresting cell cycle, attempts were made to design, synthesize and characterize two new Pa based tetradentate ligands (DPPTR and DPPTY) with a modified procedure. The procedure reported here avoids by-products and provides better yield and purity.

\section{Keywords}

\section{Amide Bond Formation, Tetradentate Ligand, Peptide Bond, Coupling Reagent}

\section{Introduction}

Synthesis of ligands with peptide bond has attracted lot of attention due to their importance in biological systems. Many reagents were used to get the desired peptides [1]-[5]. Among them DCC (N,N'-dicyclohexylcarbodiimide), EDCI (3-(Ethyliminomethyleneamino)-N,N-dimethylpropan-1-amine), HOBT (1-Hydroxybenzotriazole) and HATU (1-[Bis(dimethylamino)methylene]-1H-1,2,3-triazolo[4,5-b]pyridinium 3-oxid hexafluorophosphate) were extensively used [6]-[11]. However, with DCC and EDCI-HOBT, there is a possibility of by-product formation, reduction in the yield and makes purification difficult. With DCC, multiple by-products like anhydride, urea and $\mathrm{N}$-acylurea were formed [12] [13]. To avoid this HATU was used earlier for the synthesis of simple peptides [14] [15]. In view of this, We adopted a modified procedure employing HATU and DIEA (N,N-Diisopropylethylamine) for the synthesis of tetradentate ligand involving peptide bond. The base (DIEA) has an advantage due to the presence of an isopropyl group which helps in increasing the basicity on $\mathrm{N}$-atom and facili-

"Corresponding author. 
tates the proton abstraction from the acid. Since Pa and their derivatives are known to prevent the cell growth and arrest the cell cycle [16], it was thought important to design, synthesize and characterize two new Picolinic acid based tetradentate ligands, $\mathrm{N}$-(3-(1H-indol-3-yl)-1-oxo-1-(pyridine-2-yl methylamino)propan-2-yl) picolinamide (DPPTR) and N-3-(4-hydroxyphenyl)-1-oxo-1-(pyridine-2-ylmethylamino) propan-2-yl) picolinamide (DPPTY) using HATU and DIEA. The synthesis of ligands involves three steps (Scheme 1). The intermediates and final ligands were isolated and characterized. The results show that the yields for the intermediates are $>90 \%$ and for final ligands $>80 \%$ with good purity.

\section{Results and Discussion}

\subsection{DPTR-I/DPTY-I}

The ESI-Mass spectra of DPTR-I (Figure 1) shows $\mathrm{m} / \mathrm{z}$ peak at 324 indicating that the DPTR-I molecular ion species appeared as $[\mathrm{M}+\mathrm{H}]^{+}$and for DPTY-I (Figure 2, (Suppl Material, SM)) the mass spectra shows a peak at 301 specifying that the DPTY-I molecular ion species also appeared as $[\mathrm{M}+\mathrm{H}]^{+}$. The M.ps $130^{\circ} \mathrm{C}-133^{\circ} \mathrm{C}$ for DPTR-I and $128^{\circ} \mathrm{C}-131^{\circ} \mathrm{C}$ for DPTY-I.

${ }^{1}$ H-NMR spectra of DPTR-I/DPTY-I

DPTR-I (Figure 3): ${ }^{1} \mathrm{H}-\mathrm{NMR}\left(400 \mathrm{MHz}, \mathrm{CD}_{3} \mathrm{OH}\right): \delta=10.02$ (s, $\left.1 \mathrm{H}\right) 7.94$ (d, 1H), $7.74(\mathrm{~d}, 1 \mathrm{H}), 7.14-7.12$ (m, 2H), 6.75 - $6.72(\mathrm{~m}, 1 \mathrm{H}), 6.61(\mathrm{~d}, 1 \mathrm{H}), 6.48$ - $6.44(\mathrm{~m}, 1 \mathrm{H}), 6.29(\mathrm{~d}, 1 \mathrm{H}), 6.21$ - $6.16(\mathrm{~m}, 1 \mathrm{H}), 6.13$ - $6.05(\mathrm{~m}$, 1H), 2.77 (s, 3H), 2.72 (brs, 1H), 1.65 - 1.62 (m, 2H) [17] [18].

DPTY-I (Figure 4, SM): ${ }^{1} \mathrm{H}-\mathrm{NMR}$ (400 MHz, DMSO-d6): $\delta=9.24$ (s, 1H), 8.80 (d, 1H), 8.65 (d, 1H), 7.99 (t, 1H), 7.98 (d, 1H), 7.63 - 7.60 (m, 1H), 7.00 (d, 2H), 6.63 (d, 2H), 4.73 - 4.68 (m, 1H), 3.64 (S, 3H), 3.09 (d, 2H).

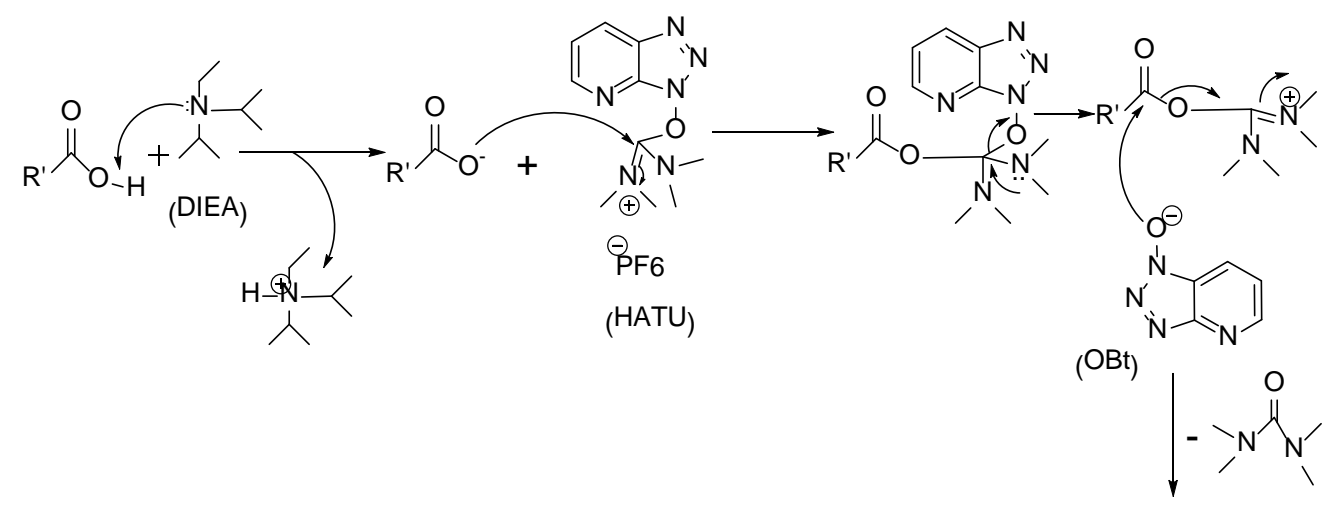<smiles>[R]C(=O)NC([R])C(=O)OC</smiles>

DPTR-I /DPTY-I<smiles>[R]=C=CC(C)Cc1ccc(C)nc1</smiles><smiles>[R]C(N=CCN(C)C(C)C)C(=O)OC</smiles>

The proposed mechanism showing the formation of DPTR-I/DPTY-I. 


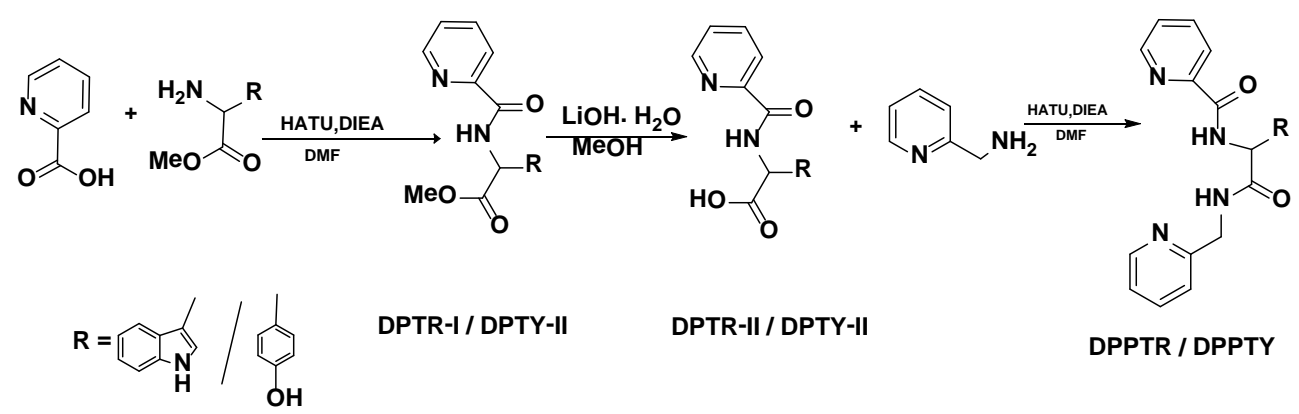

Scheme 1. Synthesis of ligands (DPPTR/DPPTY).

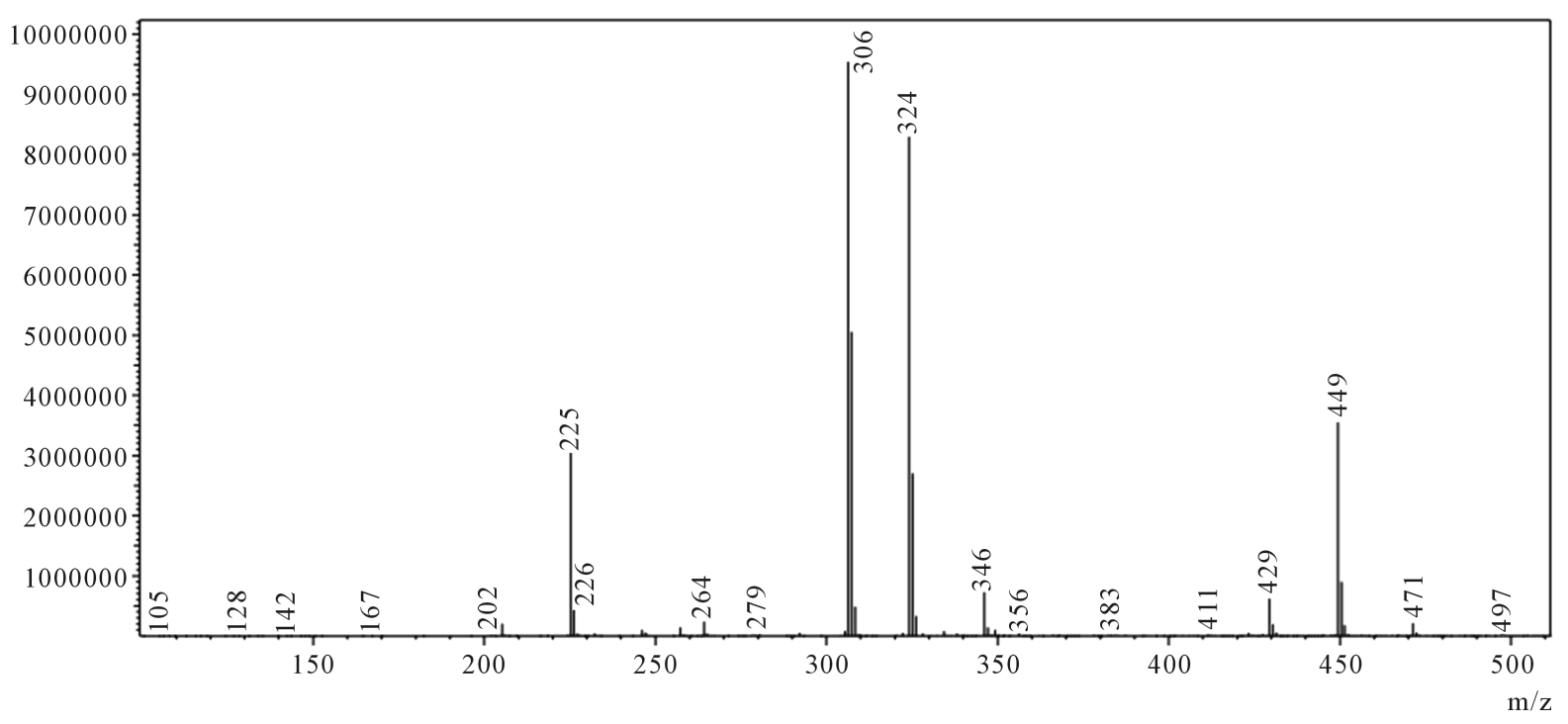

Figure 1. ESI-Mass spectra of DPTR-I.

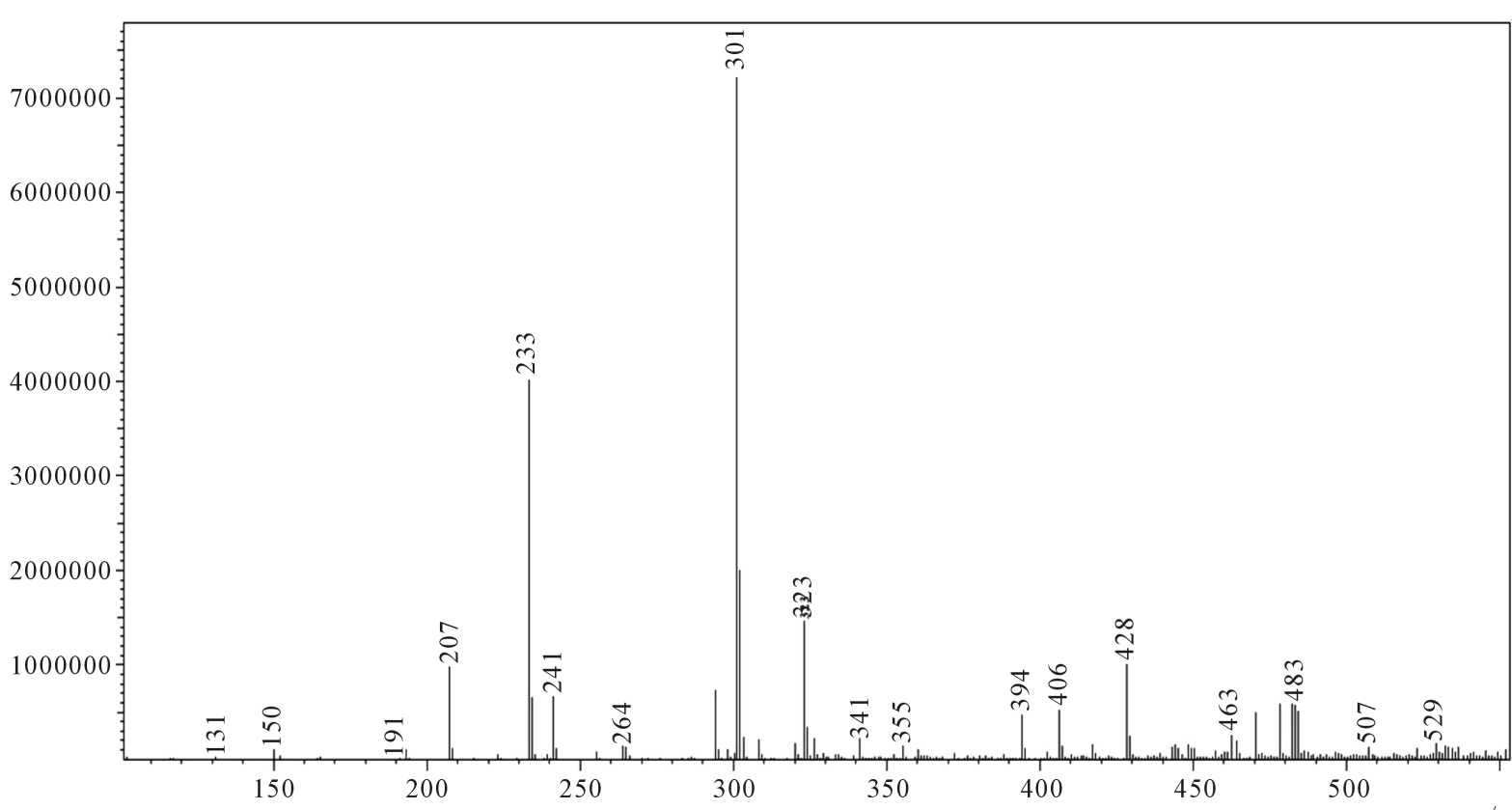

Figure 2. ESI-Mass spectra of DPTY-I. 


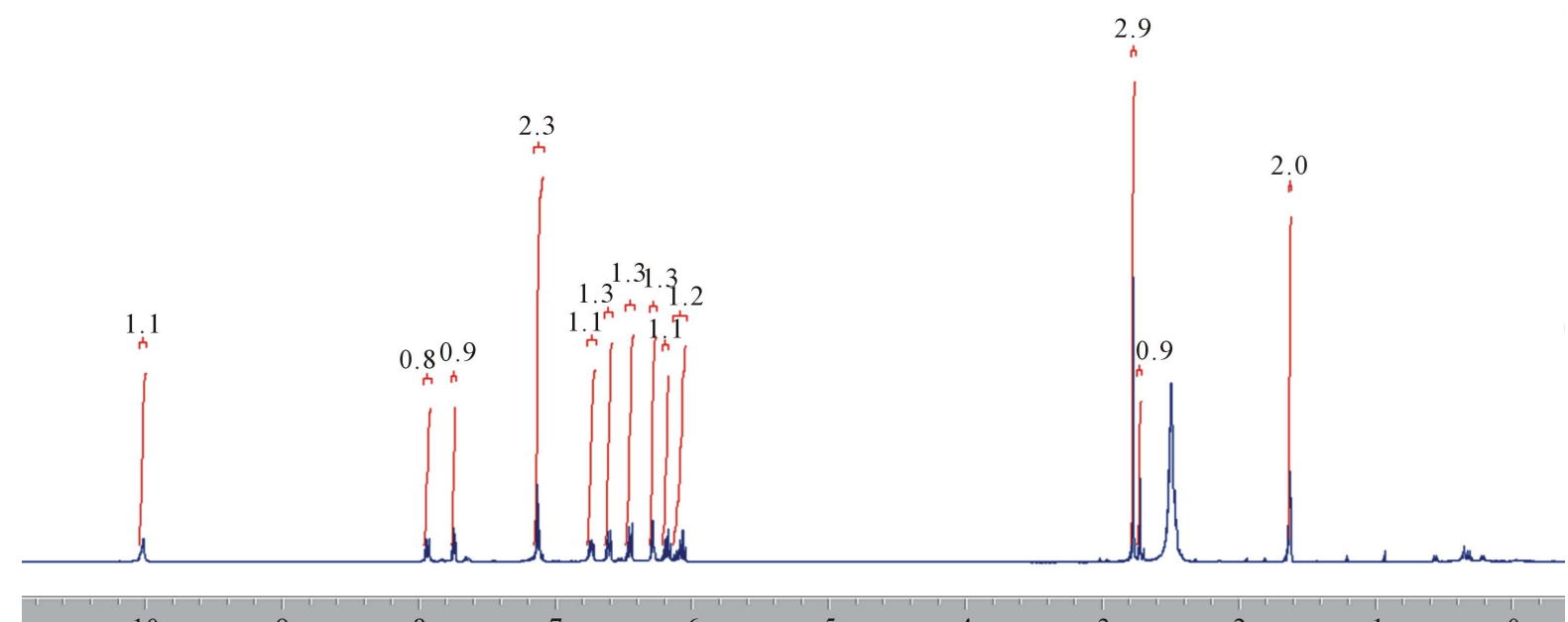

7

5

4

3

2

0

Figure $3 .{ }^{1} \mathrm{H}-\mathrm{NMR}$ spectra of DPTR-I.

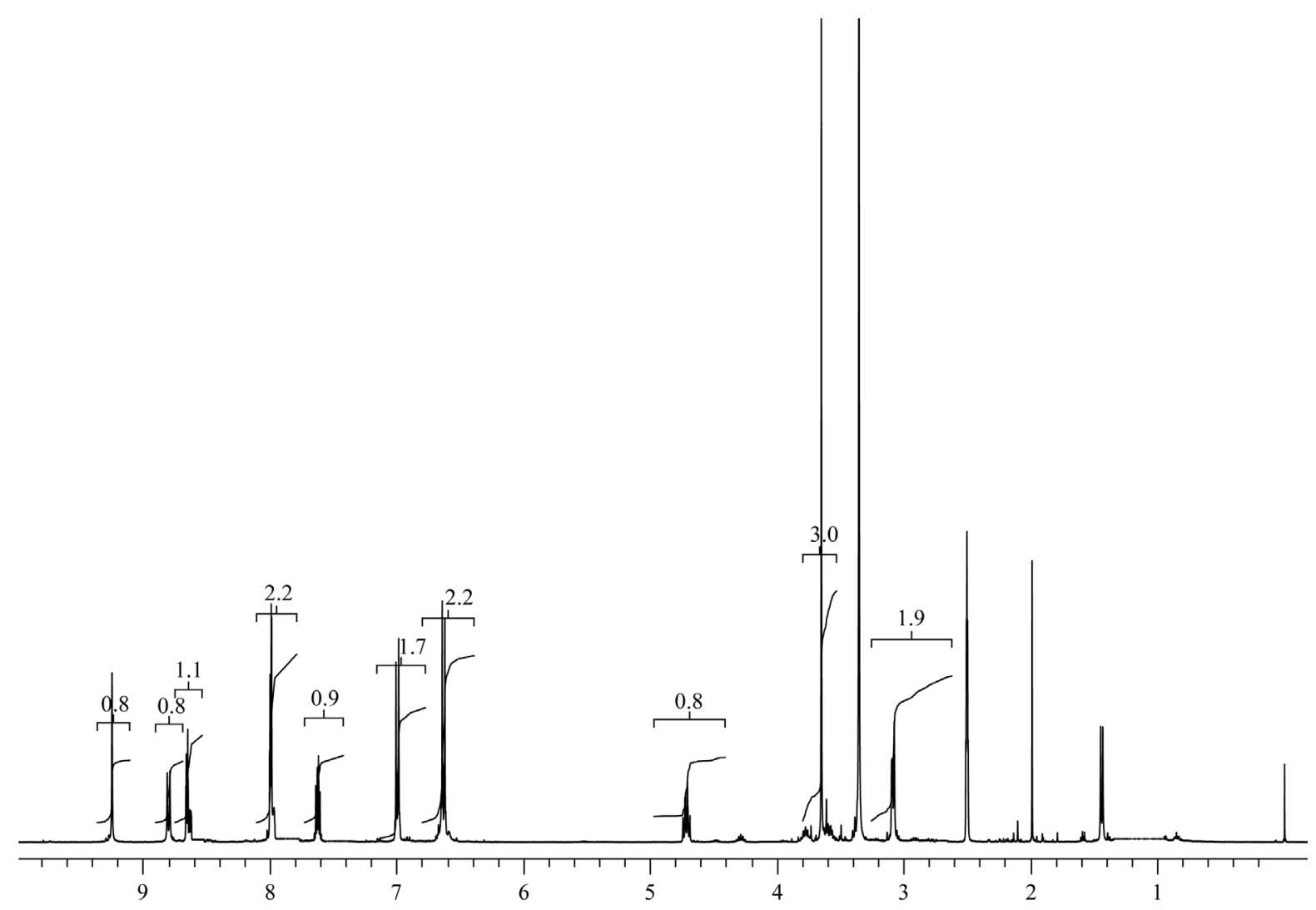

Figure 4. ${ }^{1} \mathrm{H}-\mathrm{NMR}$ spectra of DPTY-I.

The mechanism involves,

1) Proton abstraction occurs from Pa followed by the addition of carboxylate anion (-Coo $\left.{ }^{-}\right)$to the electron deficient carbon atom of HATU. This results in the formation of new C-O bond.

2) The resulting anion reacts with the newly formed activated carboxylic acid derived from intermediate to form an OBt activated ester.

3) The amine reacts with the OBt activated ester to form the amide product.

Similar mechanism was proposed earlier for the formation of amide bond [19]-[21]. 


\subsection{DPTR-II/DPTY-II}

The ESI-Mass spectra of DPTR-II (Figure 5) shows $m / z$ peak at 315 suggesting that the DPTR-II molecular ion species appeared as $[\mathrm{M}+\mathrm{Li}]^{+}$and for DPTY-II (Figure 6, SM) the mass spectra shows a peak at 287 indicating that the DPTY-II molecular ion species appeared as $[\mathrm{M}+\mathrm{H}]^{+}$. The M.ps $131^{\circ} \mathrm{C}-134^{\circ} \mathrm{C}$ for DPTR-II and $129^{\circ} \mathrm{C}-$ $132^{\circ} \mathrm{C}$ for DPTY-II.

${ }^{1} \mathrm{H}$-NMR spectra of DPTR-II/DPTY-II

DPTR-II (Figure 7): ${ }^{1}$ HNMR (400 MHz, DMSO-d $\left.\mathrm{d}_{6}\right): \delta=9.88$ (s, 1H), $7.67(\mathrm{~d}, 1 \mathrm{H}), 7.19$ - 7.08 (m, 3H), 6.69 $6.66(\mathrm{~m}, 1 \mathrm{H}), 6.58(\mathrm{~d}, 1 \mathrm{H}), 6.37(\mathrm{~d}, 1 \mathrm{H}), 6.19(\mathrm{~d}, 1 \mathrm{H}), 6.09$ - $6.05(\mathrm{~m}, 1 \mathrm{H}), 5.93$ - $5.89(\mathrm{~m}, 1 \mathrm{H}), 3.40$ - $3.38(\mathrm{~m}$, $1 \mathrm{H}), 2.37$ - $2.32(\mathrm{~m}, 2 \mathrm{H})$.

DPTY-II (Figure 8, SM): 1H-NMR (400 MHz, DMSO-d6): $\delta=9.22$ (s, 1H), 8.65 - 8.60 (m, 2H), 8.01 - 7.98 (m, 2H), $7.62(\mathrm{~d}, 1 \mathrm{H}), 6.99(\mathrm{~d}, 2 \mathrm{H}), 6.22(\mathrm{~d}, 2 \mathrm{H}), 4.67$ - $4.62(\mathrm{~m}, 1 \mathrm{H}), 3.08(\mathrm{~d}, 2 \mathrm{H})$.

\section{IR spectra of DPTR-II/DPTY-II}

The IR spectra for the above intermediates were recorded to confirm the presence of acidic proton (COOH functional group).

DPTR-II (Figure 9): IR $v_{\max }$ (MeOH): $3323(\mathrm{CONH}), 3098(\mathrm{COOH}), 1625(\mathrm{C}=\mathrm{O}), 1516(\mathrm{C}=\mathrm{C}) 1437(\mathrm{C}=\mathrm{N})$, 1245 (C-N) $\mathrm{cm}^{-1}$ [22].

DPTY-II (Figure 10, SM); IR $v_{\max }(\mathrm{MeOH}): 3330$ (CONH), 2956 (COOH), 1739 (C=O), 1439 (C=C), 1367 $(\mathrm{C}=\mathrm{N}), 1218(\mathrm{C}-\mathrm{N}) \mathrm{cm}^{-1}$.
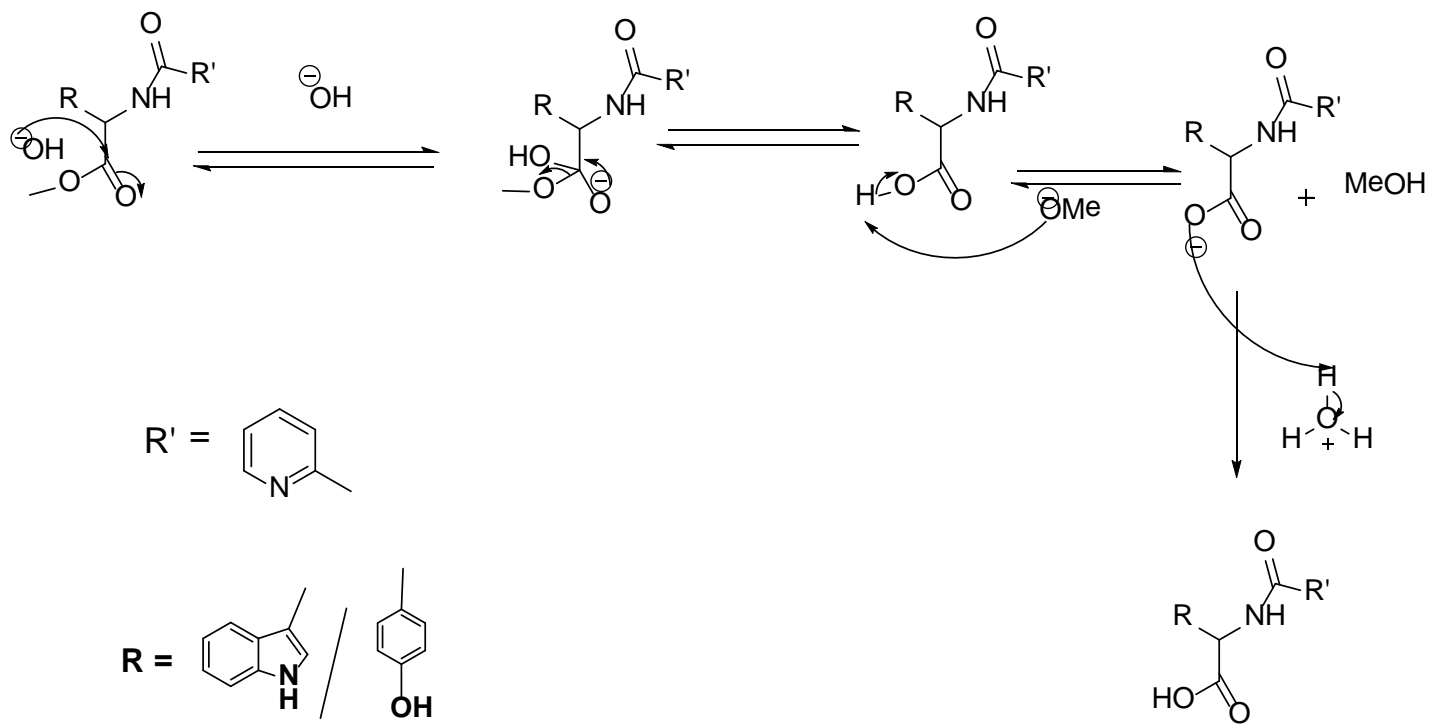<smiles>[R]C(=O)NC([R])C(=O)O</smiles>

DPTR-II / DPTY-II

The proposed mechanism showing the formation of DPTR-II/DPTY-II.

The general mechanism for the de-esterification by base involves a series of equilibria. The hydroxide anion adds to the carbonyl group of the ester. The direct products are a carboxylic acid salt and an alcohol. To convert the salt to the corresponding carboxylic acid, acidic workup of the product mixture was performed [23].

\subsection{Final Ligands: DPPTR/DPPTY}

The ESI-Mass spectra of DPPTR-(Figure 11) shows $m / z$ peak at 400 indicating that the DPPTR molecular ion species appeared as $[\mathrm{M}+\mathrm{H}]^{+}$and for DPPTY (Figure 12, SM) the mass spectra shows a peak at 377 suggesting that the DPPTY molecular ion species appeared as $[\mathrm{M}+\mathrm{H}]^{+}$. The M.ps $136^{\circ} \mathrm{C}-138^{\circ} \mathrm{C}$ for DPPTR and $133^{\circ} \mathrm{C}-$ $135^{\circ} \mathrm{C}$ for DPPTY.

${ }^{1} \mathrm{H}$-NMR spectra of DPPTR/DPPTY

DPPTR (Figure 13); 1H-NMR (400 MHz, DMSO-d6): $\delta=10.68$ (s, 1H), 9.82 (d, 2H), 8.59 - 8.50 (m, 1H), 


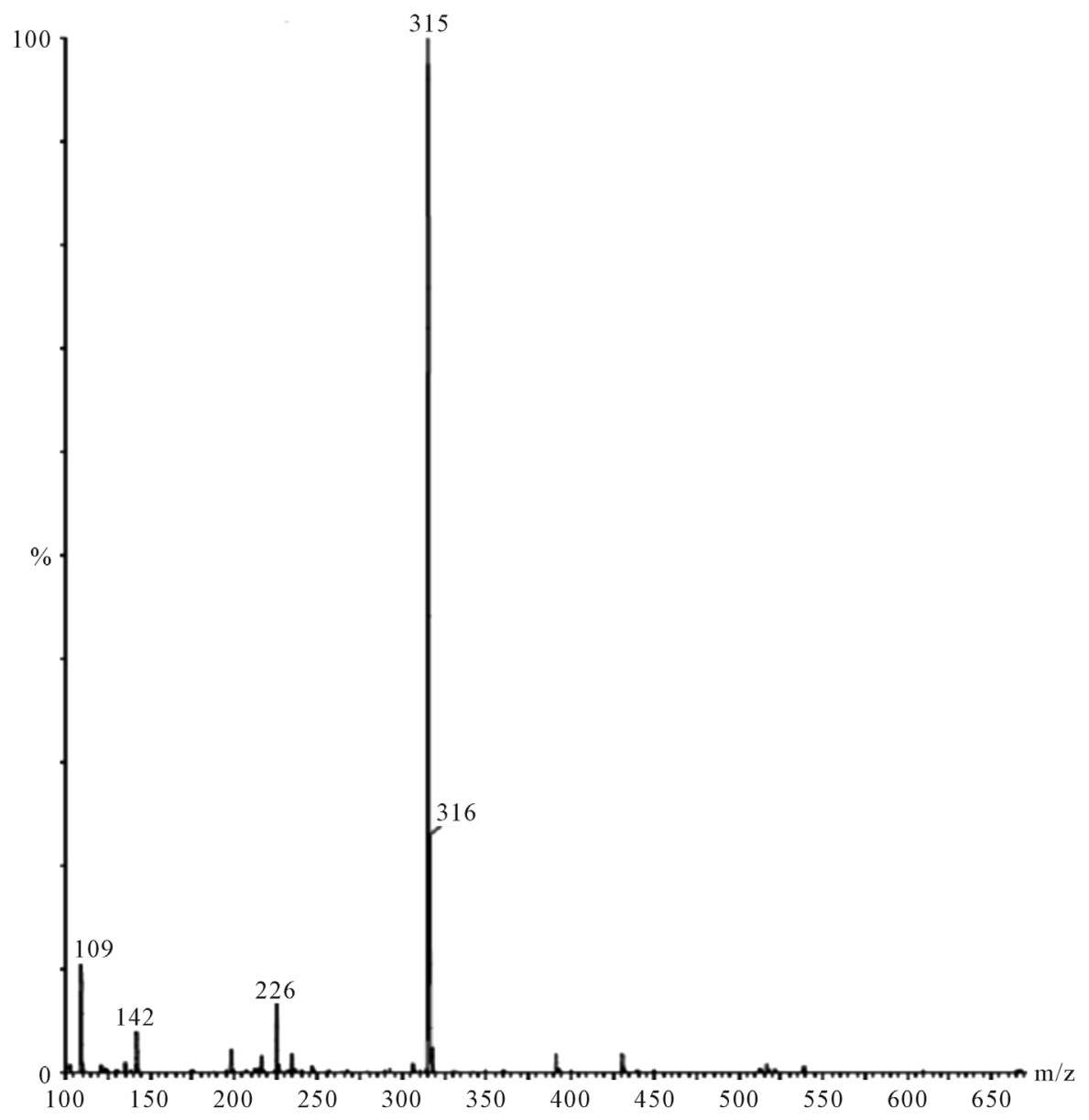

Figure 5. ESI-Mass spectra of DPTR-II.

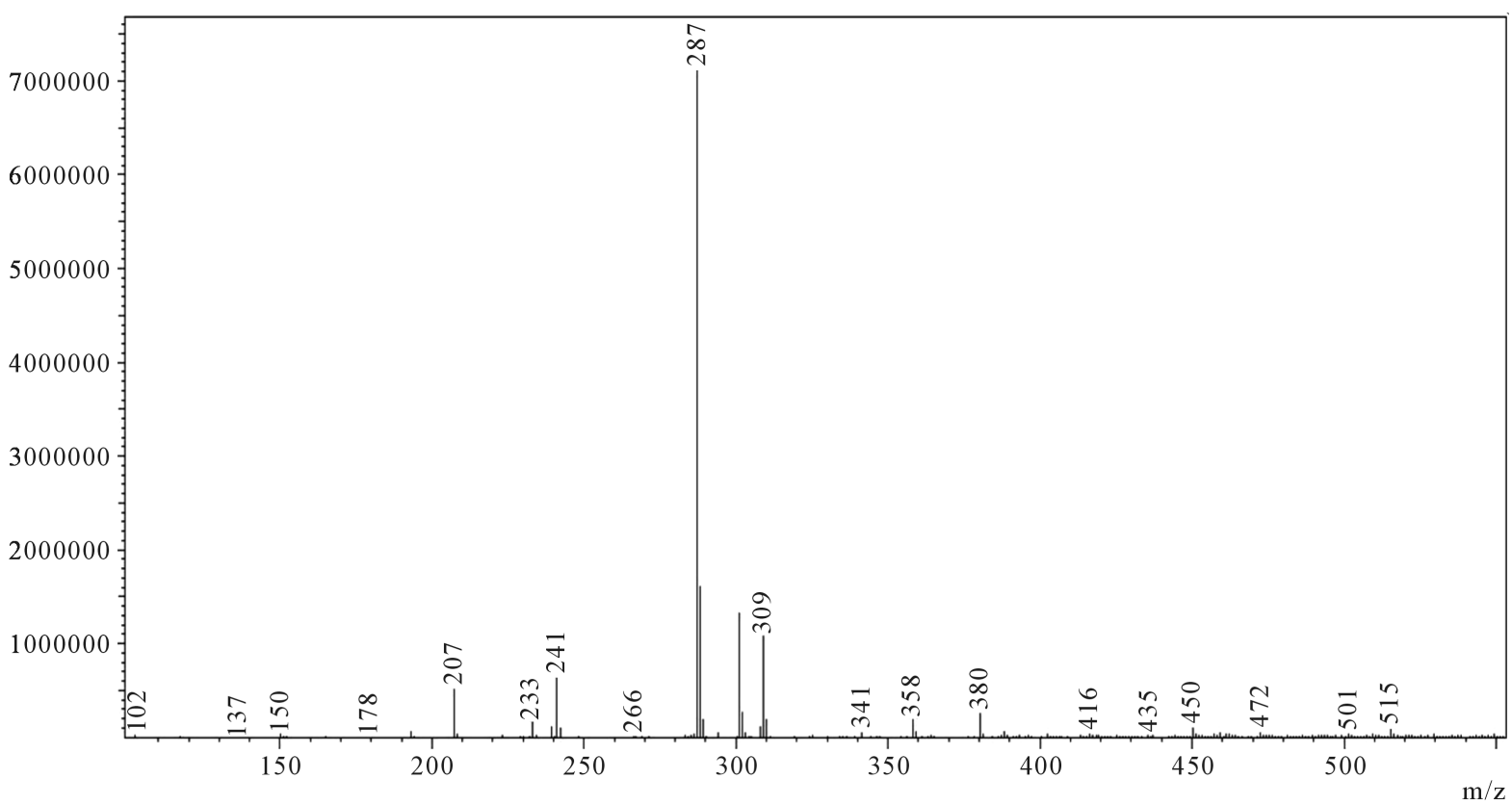

Figure 6. ESI-Mass spectra of DPTY-II. 


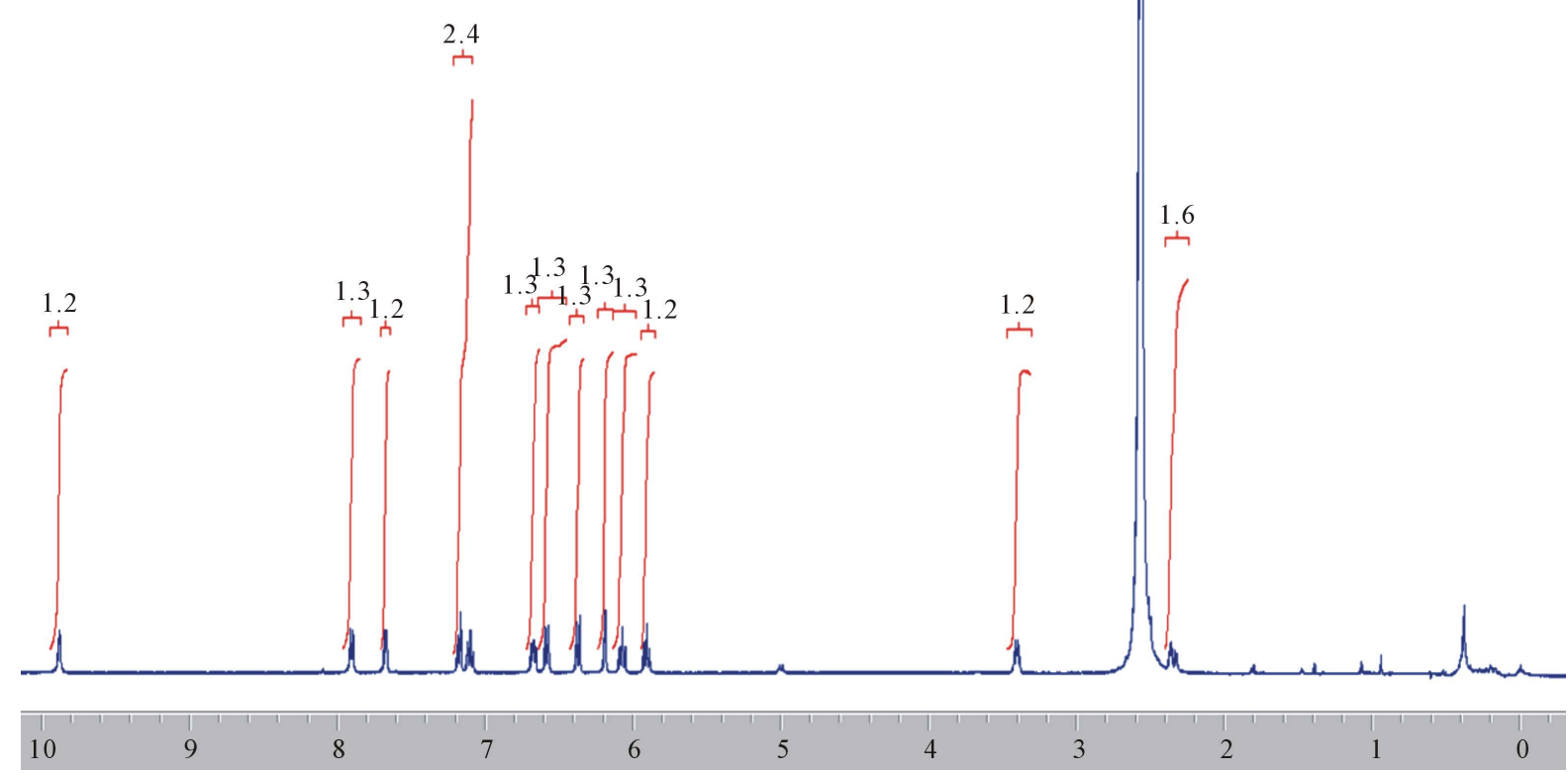

Figure $7 .{ }^{1} \mathrm{H}-\mathrm{NMR}$ spectra of DPTR-II.

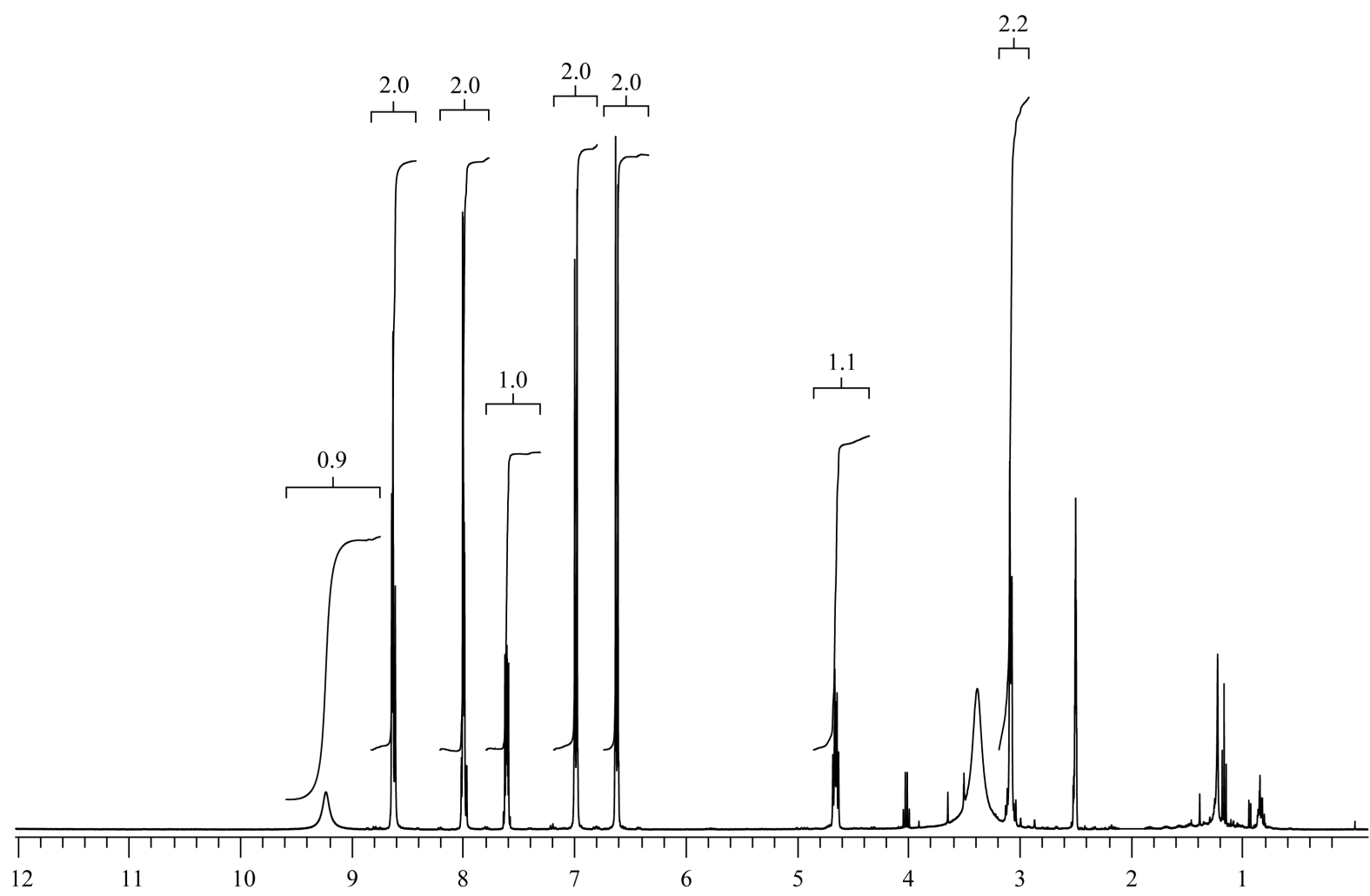

Figure 8. ${ }^{1} \mathrm{H}$-NMR spectra of DPTY-II. 


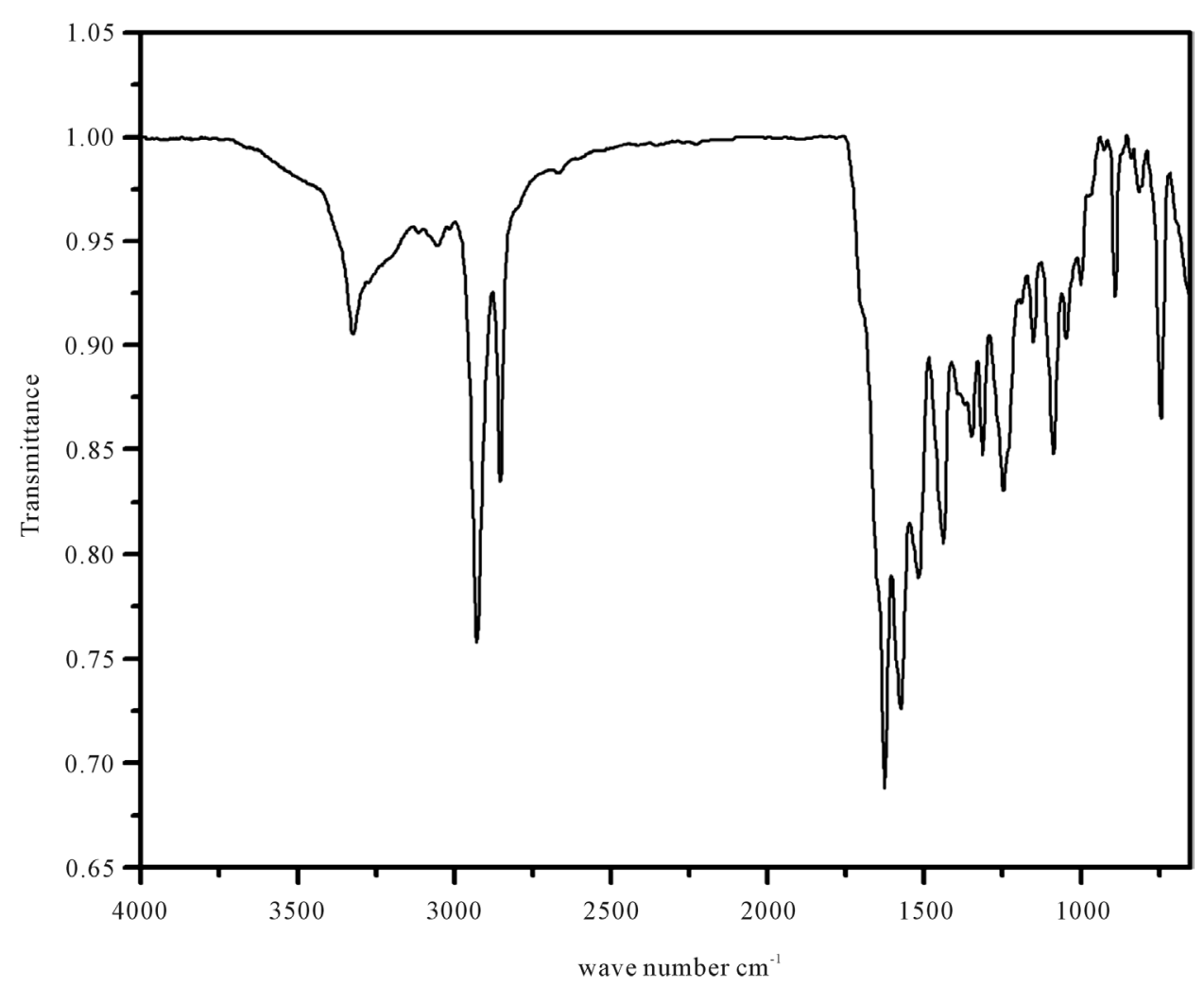

Figure 9. Infrared spectra of DPTR-II.

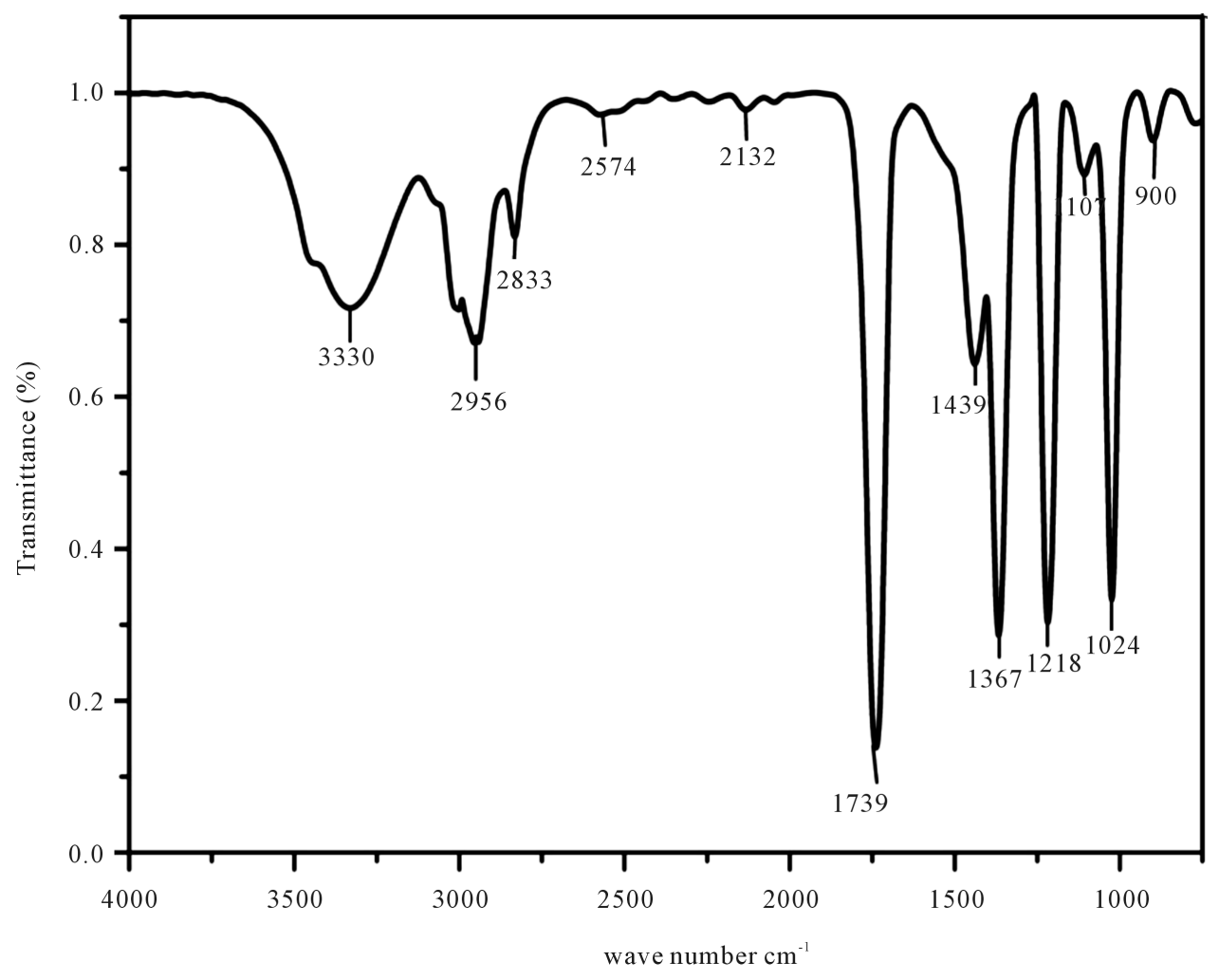

Figure 10. Infrared spectra of DPTY-II. 
P. R. Reddy et al.

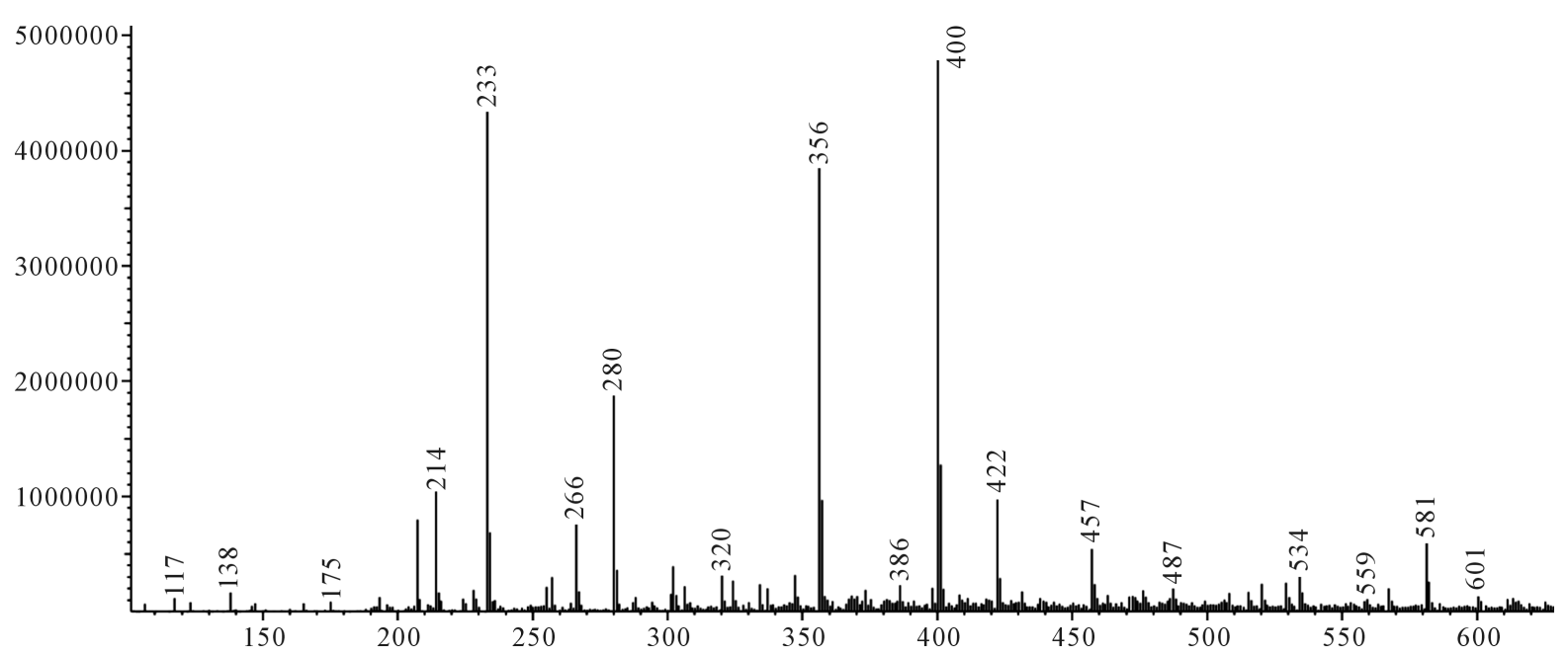

Figure 11. ESI-Mass spectra of DPPTR.

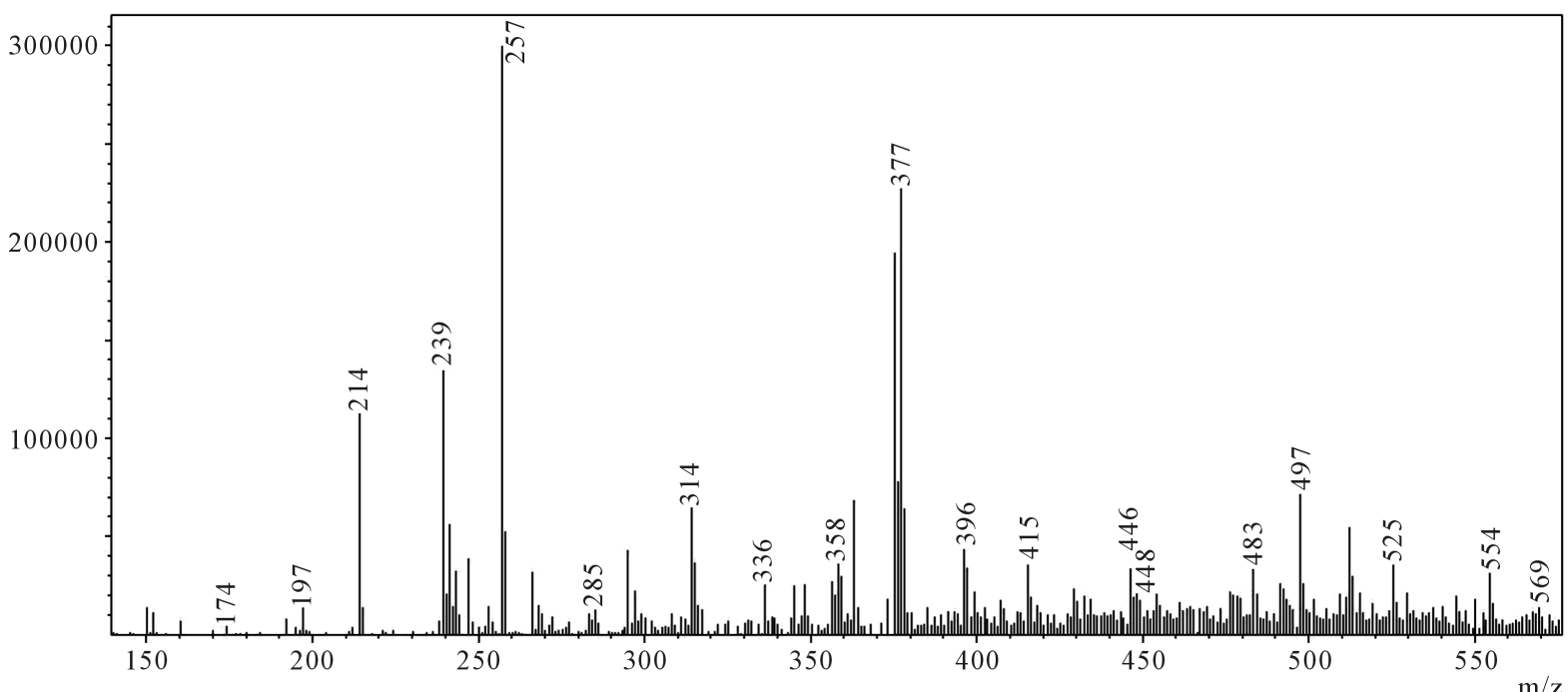

Figure 12. ESI-Mass spectra of DPPTY.

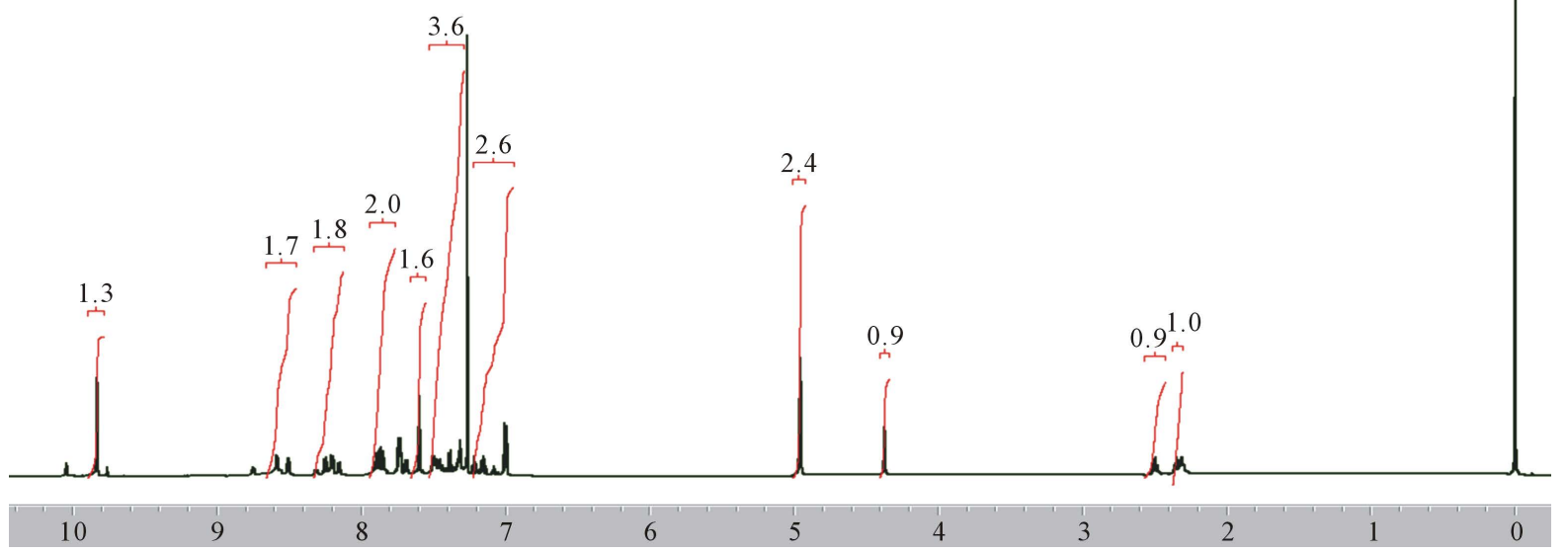

Figure 13. ${ }^{1} \mathrm{H}-\mathrm{NMR}$ spectra of DPPTR. 
8.26 - 8.14 (m, 2H), 7.91 - $7.85(\mathrm{~m}, 2 \mathrm{H}), 7.74-7.67$ (m, 2H), 7.59 (s, 1H), 7.50 - $7.31(\mathrm{~m}, 2 \mathrm{H}), 7.23$ - 7.08 (m, $1 \mathrm{H}), 7.01$ - $6.99(\mathrm{~m}, 1 \mathrm{H}), 4.95$ (d, 3H), 4.37 (d, 1H), 2.50 - $2.47(\mathrm{~m}, 1 \mathrm{H}), 2.36-2.31(\mathrm{~m}, 1 \mathrm{H})$

DPPTY (Figure 14, SM); 1-HNMR (400 MHz, DMSO-d $\left.\mathrm{d}_{6}\right): \delta=8.82(\mathrm{t}, 1 \mathrm{H}), 8.65(\mathrm{t}, 2 \mathrm{H}), 8.48(\mathrm{~d}, 1 \mathrm{H}), 8.02$ (d, 2H), $7.75(\mathrm{t}, 1 \mathrm{H}), 7.62-7.59(\mathrm{~m}, 1 \mathrm{H}), 7.25(\mathrm{t}, 1 \mathrm{H}), 7.10(\mathrm{~d}, 1 \mathrm{H}), 7.00(\mathrm{~d}, 2 \mathrm{H}), 6.60(\mathrm{~d}, 2 \mathrm{H}), 4.79-4.74(\mathrm{~m}$, 1H), 4.43 - $4.34(\mathrm{~m}, 2 \mathrm{H}), 3.06-2.99(\mathrm{~m}, 2 \mathrm{H})$.

\section{IR spectra of DPPTR/DPPTY}

DPPTR (Figure 15): IR $v_{\max }(\mathrm{MeOH}): 3307(\mathrm{CONH}), 1660(\mathrm{C}=\mathrm{O}), 1516 \mathrm{~cm}^{-1}(\mathrm{C}=\mathrm{C}), 1478(\mathrm{C}=\mathrm{N}), 1232$ (C-N) $\mathrm{cm}^{-1}$.

DPPTY (Figure 16, SM): IR $v_{\max }(\mathrm{MeOH}): 3323(\mathrm{CONH}), 1741(\mathrm{C}=\mathrm{O}), 1371(\mathrm{C}=\mathrm{C}), 1443(\mathrm{C}=\mathrm{N}), 1224$ (C-N) $\mathrm{cm}^{-1}$.

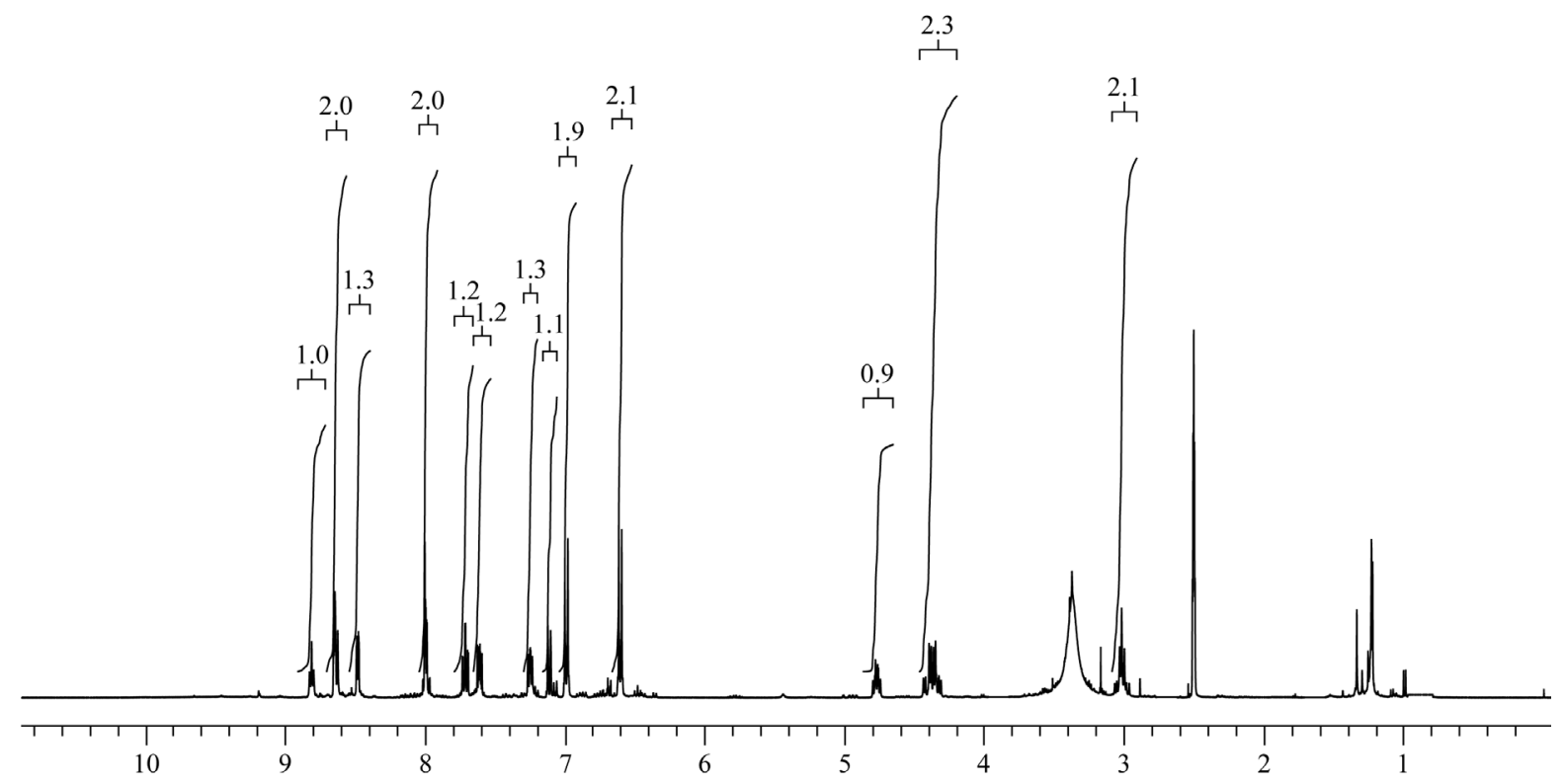

Figure 14. ${ }^{1} \mathrm{H}-\mathrm{NMR}$ spectra of DPPTY.

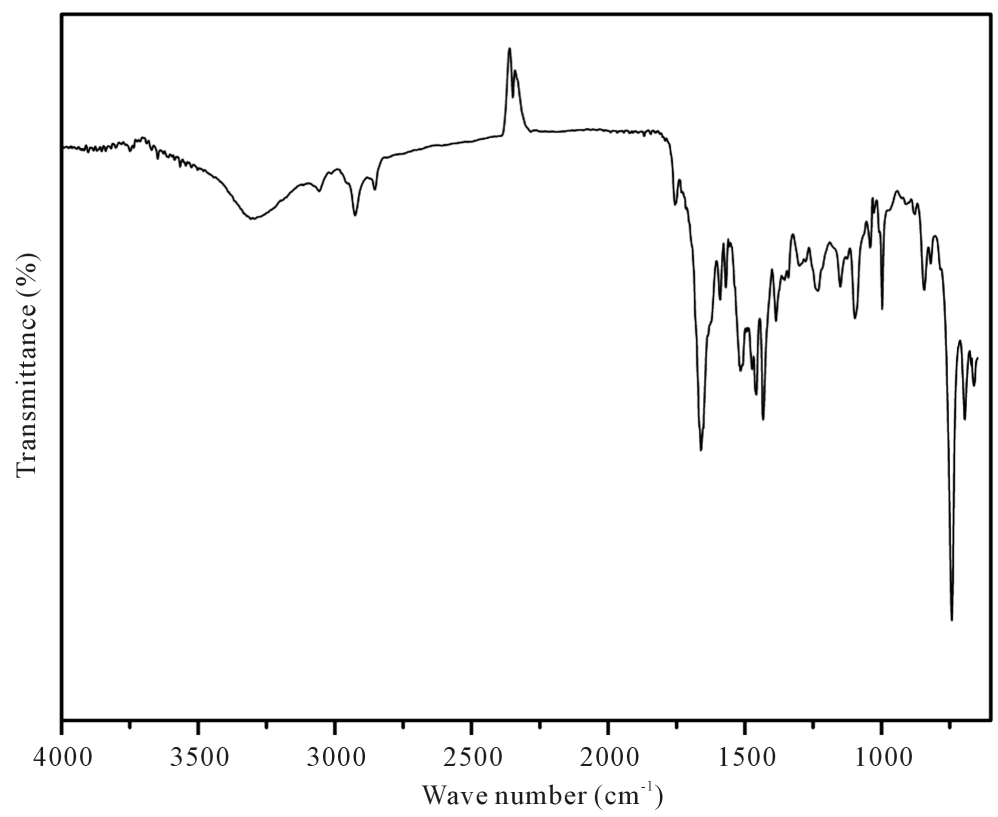

Figure 15. Infrared spectra of DPPTR. 


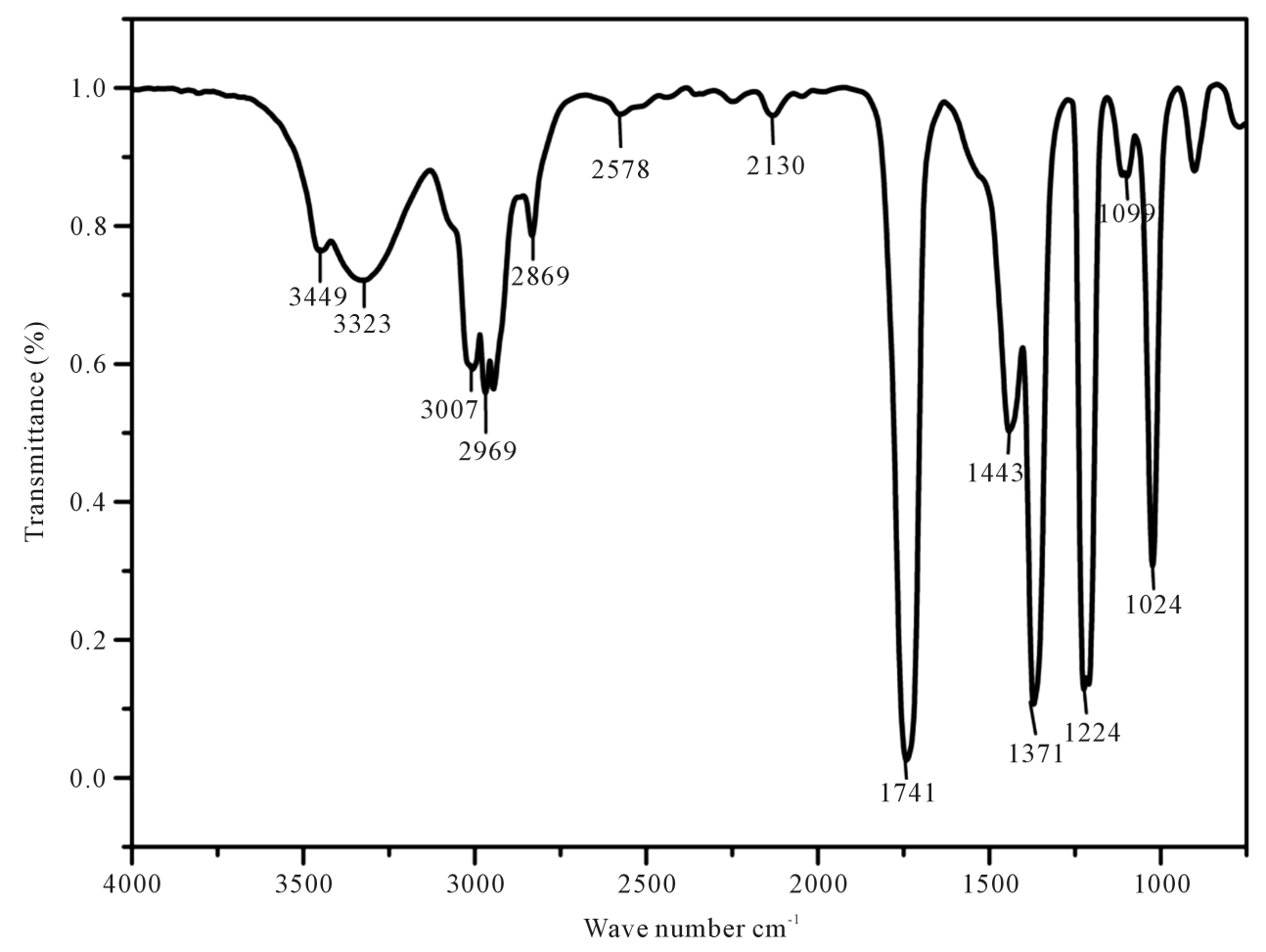

Figure 16. Infrared spectra of DPPTY.

The mechanism for the formation of final ligands is similar to that described for the formation of DPTR-I/ DPTY-I except that the starting materials are different.

\section{Conclusion}

Two new tetradentate ligands involving peptide bond were synthesized with a modified procedure and characterized. The procedure is simple and avoids by-products and results in better yields. Since small molecular bio-ligands containing peptide bond are known to play an important role as biomimetics, construction of such mimics can lead to a better understanding of the biological complexity at a molecular level. Therefore, the procedure described here will provide an opportunity to synthesize new small molecules.

\section{Experimental Section}

\subsection{Material and Methods}

Picolinic acid, Tryptophan-methyl ester, Tyrosine-methyl ester, picolylamine and $\mathrm{LiOH} \cdot \mathrm{H}_{2} \mathrm{O}$ are obtained from sigma chemical company (99\% purity), USA. HATU and solvents (DIEA, methanol, Ethylacetate, n-Hexane and dimethylformamide) were purchased from Merck, India and were of analar grade. The chemicals were used as supplied. The TLC silica gel plates $\left(60 \mathrm{~F}_{254}\right)$ were obtained from Merck. Infrared spectra were recorded on a Perkin-Elmer FT-IR spectrometer in the range of $4000-750 \mathrm{~cm}^{-1}$ using Methanol as solvent. ESI mass spectra for the ligands were recorded on a Quattro Lc (Micro mass, Manchester, UK) triple quadruple mass spectrometer with Mass Lynx software and Shimadzu, model LC-MS; 8030. The ${ }^{1} \mathrm{H}-\mathrm{NMR}$ spectra were recorded on a Bruker Biospin and Avance-III $400 \mathrm{MHz}$ Fourier Transform Digital NMR Spectrometer, Switzerland using DMSO as solvent and TMS as the internal standard. The melting points were recorded on a cintex melting point instrument and are uncorrected. All reactions were carried under $\mathrm{N}_{2}$ atmosphere.

\subsection{Synthesis of Peptides}

The synthesis of peptides involves three steps (Scheme 1). The following procedure was adopted for the synthesis. 


\section{DPPTR:}

For the synthesis of DPPTR, 2-picolinic acid $(0.2 \mathrm{~g}, 1.62 \mathrm{mmol})$ was dissolved in dry DMF $(10 \mathrm{~mL})$ and HATU $(0.74 \mathrm{~g}, 1.95 \mathrm{mmol})$ and DIEA $(0.62 \mathrm{~g}, 4.86 \mathrm{mmol})$ were added. The solution was cooled to $0^{\circ} \mathrm{C}$. The solution was stirred for $30 \mathrm{~min}$ followed by the addition of Tryptophan-methyl ester $(0.62 \mathrm{~g}, 2.43 \mathrm{mmol})$. The mixture was warmed to room temperature and the stirring continued for another $12 \mathrm{~h}$. After the workup, the solvent was removed under reduced pressure and the remaining solid was washed with petroleum ether to afford the compound, DPTR-I (yield: $0.481 \mathrm{~g}, 93 \%$ ). In the second step, the protected methyl ester (OMe) was removed by saponification using $\mathrm{LiOH}$ in $\mathrm{MeOH}$ to get DPTR-II. It was purified by column chromatography (yield: 0.419 g, 91\%). Finally, DPTR-II (0.42 g, $1.35 \mathrm{mmol})$ was dissolved in dry DMF (10 ml) and HATU $(0.61 \mathrm{~g}, 1.62 \mathrm{mmol})$ and DIEA $(0.52 \mathrm{~g}, 4.05 \mathrm{mmol})$ were added and the mixture was cooled to $0^{\circ} \mathrm{C}$. The solution was stirred for $30 \mathrm{~min}$ and the picolylamine $(0.22 \mathrm{~g}, 2.03 \mathrm{mmol})$ was added. The mixture was warmed to room temperature and stirred for another $12 \mathrm{~h}$. After the workup, the solvent was removed under reduced pressure. The residue was purified by column chromatography on silica gel (eluent: hexane/ethyl acetate) to afford the compound DPPTR (yield: $0.459 \mathrm{~g}$, 85\%). The DPPTY was synthesized as per the procedure described in SM.

\section{Acknowledgements}

The financial support from the Council of Scientific and Industrial Research (01/2569/12-EMR-II) and University Grants Commission (41-286/2012-SR), Govt. of India is gratefully acknowledged.

\section{References}

[1] Han, S.-Y. and Kim, Y.-A. (2004) Recent Development of Peptide Coupling Reagents in Organic Synthesis. Tetrahedron, 60, 2447-2467. http://dx.doi.org/10.1016/j.tet.2004.01.020

[2] Al berico, F. (2004) Developments in Peptide and Amide Synthesis. Current Opinion in Chemical Biology, 8, $211-221$. http://dx.doi.org/10.1016/j.cbpa.2004.03.002

[3] Bodanszky, M. and Bodansky, A. (1984) The Practice of Peptide Synthesis. Springer, New York.

[4] Sheehan, J.C. and Hess, G.P. (1955) A New Method of Forming Peptide Bonds. Journal of the American Chemical Society, 17, 1067-1068. http://dx.doi.org/10.1021/ja01609a099

[5] Valuer, E. andBradley, M. (2009) Amide Bond Formation: Beyond the Myth of Coupling Reagents. The Royal Society of Chemistry, 38, 606-631.

[6] Sheehan, J.C., Cruickshank, P.A. and Boshart, G.L. (1961) Convenient Synthesis of Water-Soluble Carbodiimides. The Journal of Organic Chemistry, 26, 2525-2528. http://dx.doi.org/10.1021/jo01351a600

[7] Himaja, M., Prathap, K.J., Mali, S.V. and Ramana, M.V. (2011) Synthesis Antibacterial and Insecticidal of a New Series of 4-(5-Methyl-1,2,4-triazolo[1,5-a]pyridine-7-ylamino)-N-(aryl)benzamides. Indian Journal of Hetero Cyclic Chemistry, 20, 317-320.

[8] Brogly, L., Dappen, M., Thorsett, E. and Tucker, J. (2001) Amide Bond Formation Using HATU in High throughput Synthesis. Proceedings of the 222nd ACS Nation Meeting, Chicago, 26-30 August 2001, MEDI-112.

[9] Xiao, Z., Yang, M.G., Li, P. and Percy, H. (2009) Synthesis of 3-Subbstited-4(3H)-Quinazolinones via HATU-Mediated Coupling of 4-Hydroxyquinazolines with Amines. Organic Letters, 11, 1421-1424. http://dx.doi.org/10.1021/ol802946p

[10] Prasad, B., Sambarkar, A. and Patil, C. (2012) Synthesis of Amides from Acids and Using Coupling Reagents. Journal of Current Pharmaceutical Research, 10, 22-24.

[11] Glunz, P.W. (2004) Preparation of Pyrrolo[1,2-a]Pyrimidinones as Coagulation Cascade Inhibitors. From PCT Int. Appl., WO2004002406 A2 20040108.

[12] Joullie, M.M. and Lassen, K.M. (2010) Evolution of Amide Bond Formation. ARKIVOC, viii, 189-250.

[13] Londregan, A.T., Storer, G., Wooten, C., Yang, X.J. and Warmus, J. (2009) An Improved Amide Coupling Procedure for the Synthesis of N-(Pyridin-2-yl)Amines. Tetrahedron Letters, 50, 1986-1988. http://dx.doi.org/10.1016/j.tetlet.2009.02.071

[14] Tran, T.P., Mullins, P.B., am Ende, C.W. and Pettersson, M. (2013) Synthesis of Pyridopyrazine-1,6-Diones from 6Hydroxypicolinic Acids via One-Pot Coupling/Cyclization Reaction. Organic Letters, 15, 642-645. http://dx.doi.org/10.1021/ol303463e

[15] ChemBark. News, Analysis, and Commentary for the World of Chemistry \& Chemical Research, Amide Bond Formation Using HATU. http://block.chembark.com/2007/04/01 
[16] Zhang, H.K., Zhang, X., Mao, B.Z., Li, Q. and He, Z.H. (2004) Alpha-Picolinic Acid, a Fungal Toxin and Mammal Apoptosis-Inducing Agent, Elicits Hypersensitive-Like Response and Enhances Disease Resistance in Rice. Cell Research, 14, 27-33. http://dx.doi.org/10.1038/sj.cr.7290199

[17] Fulmer, G.R., Miller, A.J.M., Sherden, N.H., Gottlieb, H.E., Nundelman, A., Stoltz, B.M., Bercaw, J.E. and Goldberg, K.I. (2010) NMR Chemical Schifts of Trace Impurities: Common Laboratory Solvents, Organics, and Gases in Deuterated Solvents Relevant to the Organometallic Chemist. Organometallics, 29, 2176-2179.

[18] Gottlieb, H.E., Kotlyar, V. and Nundelman, A. (1997) NMR Chemical Shifts of Common Laboratory Solvents as Trace Impurities. The Journal of Organic Chemistry, 62, 7512-7515. http://dx.doi.org/10.1021/jo971176v

[19] Carpino, L.A. (1993) 1-Hydroxy-7-Azabenzotriazole. An Efficient Peptide Coupling Additive. Journal of the American Chemical Society, 115, 4397-4398. http://dx.doi.org/10.1021/ja00063a082

[20] Carpino, L.A., Imazuumi, H., El-Faham, A., Ferrer, F.J., Zhamg, C., Lee, Y., Foxmam, B.M., Heanklein, P., Hanay, C., Mugge, C., Wensahuh, H., Klose, J., Beyermanm, M. and Bienert, M. (2002) The Uronium/Guanidinium Peptide Coupling Reagents: Finally the True Uronium Salts. Angewandte Chemie International Edition, 41, 441-445. http://dx.doi.org/10.1002/1521-3773(20020201)41:3<441::AID-ANIE441>3.0.CO;2-N

[21] Carpino, L.A., Imazumi, H., Foxman, B.M., Vela, M.J., Henklein, P., El-Faham, A., Klose, J. and Bienert, M. (2000) Comparison of the Effects of 5- and 6-HOAt on Model Peptide Coupling Reactions Relative to the Cases for the 4- and 7-Isomers. Organic Letters, 2, 2253-2256. http://dx.doi.org/10.1021/ol006013z

[22] Nakamoto, K. (1978) Infrared and Raman Spectra of Inorganic and Coordination Compounds. 3rd Editon, John Wiley \& Sons, New York, 228.

[23] Mc Murray, J. (1992) Organic Chemistry. 3rd Edition, Cole Publishing Company, California, 814. 